\title{
The Contribution of Host Cells to Pneumocystis Immunity: An Update
}

\author{
Patricia Otieno-Odhiambo ${ }^{1,2,3}$, Sean Wasserman $4,5 @$ and J. Claire Hoving $1,2,3,4, *(\mathbb{D}$ \\ 1 AFGrica Medical Mycology Research Unit, Institute of Infectious Diseases and Molecular Medicine, \\ University of Cape Town, Cape Town 7925, South Africa; OTNPAT001@myuct.ac.za \\ 2 Medical Research Council Centre for Medical Mycology at the University of Aberdeen, Institute of Medical \\ Sciences, Foresterhill, Aberdeen AB25 2ZD, UK \\ 3 Division of Immunology, Department of Pathology, University of Cape Town, Cape Town 7925, South Africa \\ 4 Wellcome Centre for Infectious Diseases Research in Africa, Institute of Infectious Diseases and Molecular \\ Medicine, University of Cape Town, Cape Town 7925, South Africa; sean.wasserman@uct.ac.za \\ 5 Division of Infectious Diseases and HIV Medicine, Department of Medicine, University of Cape Town, \\ Cape Town 7925, South Africa \\ * Correspondence: Jennifer.hoving@uct.ac.za
}

Received: 12 March 2019; Accepted: 16 April 2019; Published: 19 April 2019

check for updates

\begin{abstract}
Pneumocystis is a ubiquitous atypical fungus that is distributed globally. The genus comprises morphologically similar but genetically heterogeneous species that have co-evolved with specific mammalian hosts as obligate intra-pulmonary pathogens. In humans, Pneumocystis jirovecii is the causative organism of Pneumocystis pneumonia (PCP) in immunocompromised individuals, a serious illness frequently leading to life-threatening respiratory failure. Initially observed in acquired immunodeficiency syndrome (AIDS) patients, PCP is increasingly observed in immunocompromised non-AIDS patients. The evolving epidemiology and persistently poor outcomes of this common infection will require new strategies for diagnosis and treatment. A deeper understanding of host immune responses and of the cells that mediate them will improve the chance of developing new treatment strategies. This brief review provides an update on recent studies on the role of host immunity against Pneumocystis.
\end{abstract}

Keywords: Pneumocystis; Pneumocystis life forms; alveolar macrophages; dendritic cells; lymphocytes

\section{Introduction}

Sero-prevalence studies involving anti-Pneumocystis IgG in infants older than two years of age demonstrate evidence of near-universal primary infection with Pneumocystis jirovecii in early childhood, with clearance and transient colonisation throughout life [1]. Disease manifests in immunosuppressed individuals, either from reactivation of 'latent' infection acquired in childhood or through airborne transmission of new strains [1,2]. The incidence of human immunodeficiency virus (HIV)-associated Pneumocystis pneumonia (PCP), the sentinel opportunistic infection at the beginning of the AIDS epidemic, has declined dramatically in high-resource countries over the past three decades due to the introduction of potent combination antiretroviral therapy and effective chemoprophylaxis [3,4]. However, the epidemiology of PCP is shifting in these settings towards non-HIV-infected immunocompromised patients, with more widespread use of potent immunosuppressive therapy [5] in haematological malignancy, solid tumours, autoimmune conditions, and transplant recipients [6-9]. PCP incidence varies widely due to heterogeneity in study populations and designs but is reportedly as high as $15 \%$ in solid-organ transplant recipients [10] and over $18 \%$ in patients with solid tumours who are not on chemoprophylaxis [11]. HIV-negative PCP is associated 
with more rapid disease progression and worse outcomes than HIV-associated PCP [7,12], suggesting an influence of differential immune responses on clinical phenotype [13]. Case fatality is high, ranging between 20 and $67 \%[7,9,14,15]$; this variability is related to the underlying condition $[7,14]$ and severity of illness [9,15]. The prevalence of PCP in HIV-infected people of resource-limited countries remains difficult to ascertain, but it is increasingly recognised as an important cause of community-acquired pneumonia [16] and is possibly associated with a rising GDP. A recent systematic review found a prevalence of over $20 \%$ amongst inpatients presenting with respiratory symptoms in sub-Saharan Africa [17]. Outcomes are poor in these settings, with a pooled case fatality of $15 \%$ [17], reaching $60 \%$ in those admitted to ICU at one centre [18]. Improved diagnostics and treatment strategies are needed to improve patient prognosis in these settings. However, progress in the field is significantly hindered by the biotrophic nature of the Pneumocystis spp. This is a term adapted from plant fungal pathogens due to the dependence on their host for survival $[19,20]$. Therefore, Pneumocystis cannot be propagated in culture. Furthermore, Pneumocystis has strict host species specificity, with P. jirovecii infecting humans, Pneumocystis carinii infecting rats and Pneumocystis murina infecting mice. The substantial variation in the genomes of rodent and human Pneumocystis spp. suggests there may be clinically relevant differences between animal models of PCP and human disease. However, studies using animal models have provided valuable insight into understanding host immune mechanisms during infection. Ma and colleagues have elegantly summarised advances in molecular methods that have led to a better understanding of the biology and epidemiology of Pneumocystis infection [2,21]. Since being identified as a fungus using 16S rRNA gene analysis, Pneumocystis taxonomic classification has improved, and it is now classified in the monophyletic subphylum Taphrinomycotina. Molecular typing methods which identify Pneumocystis strain variation have led to an improved understanding of drug resistance and the pathogenesis of Pneumocystis species [2]. Furthermore, a recent study suggested that the virulence of $P$. jirovecii strains or genetic polymorphisms in humans could be responsible for treatment failure and high mortality in 12 Indian patients [22]. New studies continue to dissect host-pathogen interactions, with the goal of identifying key immune components capable of specifically targeting Pneumocystis. These include recognition of various life forms of Pneumocystis species by host dendritic cells (DCs) and alveolar macrophages and the role of the innate immune system in triggering the appropriate adaptive response. Ultimately, it is an effective adaptive $\mathrm{CD} 4^{+} \mathrm{T}$ cell response that is pivotal to Pneumocystis clearance. However, the specific nature of this response, and the delineation of $\mathrm{CD} 4^{+} \mathrm{T}$ helper cell subsets, Th1, Th2 and Th17, is a subject of continuous investigation. Therefore, this brief review aims to provide an update on recent developments on the host immune response to Pneumocystis species.

\section{Pneumocystis Life Forms and Host Cells}

Important in understanding the host immune response to Pneumocystis spp. is characterising the life cycle stages during infection and how these influence the host response. The Pneumocystis lifecycle has an infective ascus form and an asexual trophic form. While Pneumocystis species have developed unique mechanisms which allow them to evade immune recognition and persist in the host, the life form stages also elicit distinct immune responses which influence the outcome of disease $[23,24]$. The ascus form has up to eight ascospores and a cell wall consisting of the major surface glycoproteins (MSG), $\beta-1,3$ glucan and $\beta-1,6$ glucan. $\beta-1,3$ glucan is the most abundant and is the primary pro-inflammatory factor. Like the ascus form, the asexual trophic form expresses MSG but not $\beta$-glucans [25]. Asci $\beta$-glucan serves as a pathogen-associated molecular pattern (PAMP) that is recognised by pattern recognition receptors (PRRs) on phagocytic cells. This recognition is essential in initiating an appropriate $\mathrm{CD} 4^{+} \mathrm{T}$ cell response to drive Pneumocystis clearance, as shown in Figure 1 . Because of the lack of $\beta$-glucans, the trophic form is poorly recognised by phagocytic cells, resulting in an insufficient $\mathrm{CD} 4^{+} \mathrm{T}$ cell response. It is commonly accepted that multiple types of phagocytic cells contribute to $\mathrm{T}$ cell priming in response to Pneumocystis. However, increasing evidence suggests that the life stage form of Pneumocystis also influences the host immune response [24,26]. Specifically, Evans and colleagues proposed that asci play a primary role in inducing the host immune response by 
stimulating interferon gamma (IFN- $\gamma$ ) production by $\mathrm{CD} 4^{+} \mathrm{T}$ cells. In contrast, the trophic form hinders dendritic cell proinflammatory cytokine production elicited by $\beta$-1,3-glucan, thereby suppressing the immune response. In fact, Evans et al. proposed that suppression could indeed be beneficial for immunocompromised hosts in that the lung pathology associated with PCP is reduced [24,26]. Furthermore, $\mathrm{T}$ cells primed in the presence of the trophic form can effectively mediate the clearance of both trophic and ascus forms [27]. The majority of studies have described the role of immune cells against Pneumocystis. Recently, a study by Kottom and colleagues provided evidence for the role of airway epithelial cells in binding and recognising microorganisms to initiate the relevant signalling pathways [28]. Here, they showed that the trophic form of Pneumocystis binds to alveolar epithelial cells, aiding proliferation, but that both asci and trophs mediate a cytokine response including IL-8, IL-6, TNF $\alpha$ and Macrophage Inflammatory protein 2 (MIP-2). As future studies discriminate the host immune response on the basis of specific life forms of Pneumocystis, it will be interesting to dissect the role this plays in resolving infection and potentially identify underlying mechanisms which allow Pneumocystis to go undetected during host colonisation.

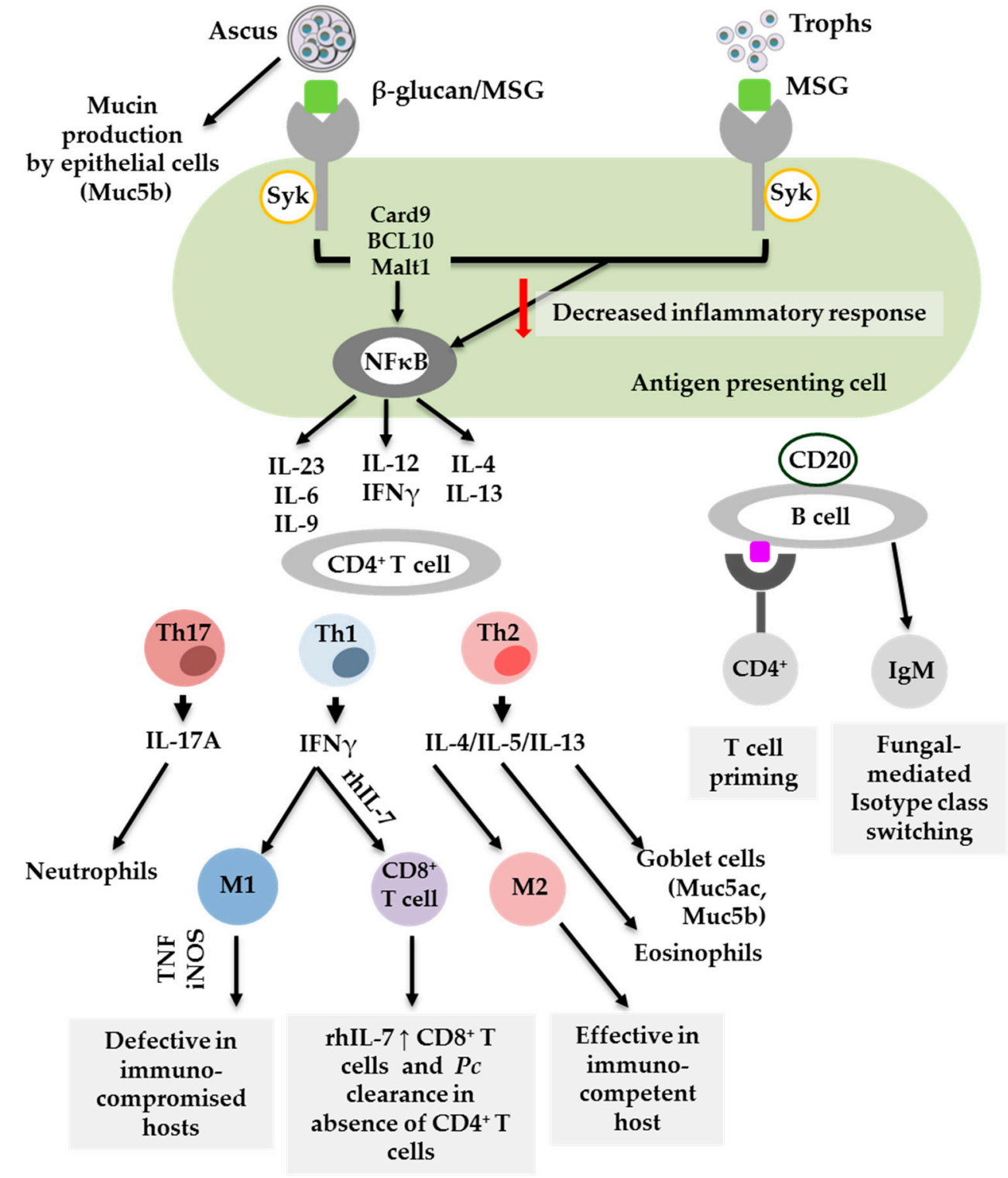

Figure 1. Cells which contribute to the host immune response to Pneumocystis. 
Significant progress has been made in understanding host immune responses to Pneumocystis through animal and human studies. The fact that Pneumocystis has multiple life stage forms influences the effectiveness of immune recognition and subsequent $\mathrm{CD} 4^{+} \mathrm{T}$ cell responses. Th1, Th2 and Th17 are implicated in Pneumocystis clearance. However, Th2 and Th17 are also associated with pathology, including mucin (Muc5ac) production. B cells are key in $\mathrm{CD}^{+} \mathrm{T}$ cell priming and as effector cells. M1 = classically activated macrophages, M2 = alternatively activated macrophages, $P_{c}=$ Pneumocystis, $\mathrm{rh}=$ recombinant human, $\mathrm{Th}=\mathrm{T}$ helper $[24,29-34]$

\section{Dendritic Cells}

Dendritic cells are professional antigen-presenting cells which elicit effector functions in the lung. Activated DCs produce cytokines and migrate to the draining lymph node where they activate $\mathrm{T}$ cell responses to antigens. This activation is important in the immunity to Pneumocystis, however limited studies have investigated the role it plays in initiating effective adaptive immune responses. Fas ligand (FasL) is important in DC activation and in regulating IL-1 $\beta$ produced by DCs [35]. Carmona et al. described the role of FasL in DC activation by Pneumocystis-derived $\beta$-glucans. Here, they demonstrated that $\beta$-glucans do indeed activate DCs through the FasL mechanism and Dectin- 1 receptor, resulting in an increase in the expression of co-stimulatory molecules and subsequent Th1 polarisation [35]. To further investigate the role of $\beta$-glucan-driven DC activation, Carmona et al. found that human DCs stimulated by Pneumocystis-derived $\beta$-glucans interact with lymphocytes to produce IL-17. This is mediated by glycosphingolipids, downstream signalling molecules, [36]. In contrast, MSG seems not to be involved in DC activation. This was shown by Sassi et al., using RNA expression, cytokine production (including TNF- $\alpha$ and IFN- $\gamma$ ) and co-stimulatory molecule expression (such as CD40, CD80 and CD86) compared with Lipopolysaccharide (LPS)-stimulated controls [37]. In summary, these studies suggest that DCs play a significant role in initiating immune responses to Pneumocystis. These responses are driven by $\beta$-glucans rather than MSG, and the trophic form may actually hinder effective DC activation, resulting in impaired $\mathrm{CD}^{+} \mathrm{T}$ cell responses.

\section{Alveolar Macrophages}

Alveolar macrophages (AMs) are key resident effector cells of alveolar spaces and critical in the clearance of lung microbes as the first line of defence. AMs are important for the recognition, phagocytosis and destruction of lung pathogens, including Pneumocystis. To achieve this, AMs have to be activated by host cytokines, such as IFN- $\gamma, \mathrm{TNF} \alpha$ and granulocyte macrophage colony stimulating factor (GM-CSF), to maximise their fungicidal activity. Upon activation, AMs destroy Pneumocystis through the production of reactive oxygen and nitrogen species. The depletion of AMs in the lung thus results in impaired Pneumocystis clearance. Furthermore, evasion of AMs enhances the survival of Pneumocystis in the alveolar spaces [38]. Undeniably, AMs are critical in Pneumocystis clearance. However, recent studies investigating the response of macrophages to Pneumocystis infection suggested that the type of macrophage activation could also be significant in, and affect the level of clearance. The activation status of macrophages is categorised as either classical (M1) or alternative (M2). It is widely accepted that M1 macrophages are effective fungicidal cells, whereas M2 macrophages play an anti-inflammatory role [39]. A study dissecting the role of M1/M2 macrophages in Pneumocystis infection found that the host immune status plays a significant role [40]. Here, immunosuppressed rats exhibited a predominantly M1 phenotype, which resulted in defective Pneumocystis clearance. In contrast, the immunocompetent rats, exhibiting M2 macrophages, cleared the Pneumocystis infection effectively. Treating immunosuppressed rats with M2 macrophages resulted in Pneumocystis clearance and reduced inflammation [40]. Furthermore, Bhagwat et al. showed that intrinsic programming of AMs confers protective innate immunity against Pneumocystis infection [41]. Essentially, they showed that mice infected with Friend Leukemia Virus B (FVB) inherently have M2 macrophages which clear Pneumocystis infection before the onset of adaptive immunity. Here, the adoptive transfer of FVB M2 macrophages to immunocompromised RAG2 ${ }^{-/-}$mice conferred protection to Pneumocystis [41]. 
Collectively, these studies show that macrophage polarization represents a potential treatment model to improve Pneumocystis-associated immuno-pathogenesis.

\section{Lymphocytes: $\mathrm{CD}^{+}{ }^{+} \mathrm{T}$ Cells, $\mathrm{CD}^{+}{ }^{\mathrm{T}}$ Cells and B Cells}

$\mathrm{CD}^{+} \mathrm{T}$ cells are crucial for Pneumocystis clearance. This has been demonstrated by the use of immunodeficient animal models, where loss of $\mathrm{CD} 4^{+} \mathrm{T}$ cells renders the animals susceptible to Pneumocystis infection. Furthermore, $\mathrm{PCP}$ is observed in patients with $\mathrm{CD}^{+} \mathrm{T}$ cell counts lower than 200 cells $/ \mathrm{mm}^{3}$. CD4 ${ }^{+} \mathrm{T}$ cells confer memory cell functions that coordinate inflammatory responses in the host by recruiting and activating effector cells, like macrophages [23,24]. However, the contribution of specific CD4 ${ }^{+} \mathrm{T}$ cell subsets needs further investigation. In mice, Pneumocystis activates Thelper cells, namely, Th1, Th2 and Th17 responses. Th17 responses are thought to play a role in Pneumocystis clearance, with selected studies suggesting the recruitment of $\mathrm{CD}^{+} \mathrm{T}$ cells producing interleukin $17 \mathrm{~A}$ (IL-17A) in the lungs of infected animals. Furthermore, neutralization of IL-17A or its counterpart IL-23 results in a significant increase in Pneumocystis lung burden at later stages of infection. In addition, mice lacking nuclear factor (NF) $-\kappa \beta$ signalling within the lung epithelium exhibit impaired fungal clearance that is associated with reduced lung IL- $17^{+} \mathrm{CD} 4^{+} \mathrm{T}$ cells $[29,38-43]$. Interestingly, Th17 cells are also thought to produce IL-9 [44]; how this influences Th17 responses to Pneumocystis remains to be determined. Investigations by $\mathrm{Li}$ et al. suggested that, despite Pneumocystis clearance in wild-type (WT) and IL-9-deficient mice, IL-9 deficiency may actually lower lung burden and promote pulmonary Th17 responses in the early stages of infection [45]. Th1 and Th2 have also been implicated in host protection against Pneumocystis. A study by Kolls et al. showed that in the absence of CD4 ${ }^{+} \mathrm{T}$ cells, artificial activation of IFN- $\gamma$ reinstates control of infection. This suggests a role for Th1 responses in conferring protection against Pneumocystis infection [46]. Similarly, Th2-associated responses and M2 macrophages are linked to protection against Pneumocystis and fungicidal activity [40,47]. In addition, Eddens and colleagues provided convincing evidence for the contribution of eosinophils in Pneumocystis clearance. In their study, RAG-1-deficient mice treated with plasmid-derived IL-5 had increased eosinophilia in the lung, with reduced Pneumocystis burden [48]. The authors proposed that it is the early response of $\mathrm{CD} 4^{+} \mathrm{T}$ cells that recruits eosinophils. In contrast, a Th2 immune response to Pneumocystis has been shown to induce pathology. That is, Th2 responses lead to an asthma-like pathology in immunocompetent individuals, similar to house dust mite-induced asthma [30]. Similarly, in rodents, Pneumocystis induced a Th2-type inflammation and airway remodelling [31]. Furthermore, the slow rise in the mucin Muc5ac during primary Pneumocystis infection suggested an ongoing Th2-type immune response linked to airway sensitization against this fungus [49]. Recently, the mucin Muc5b was shown to be increased earlier and more abundantly than Muc5ac during primary infection in rats [32]. This suggested an acute defensive response against Pneumocystis, in addition to the central effector role of Muc5ac in mediating Th2-type allergic inflammation [32]. The importance of early host responses in controlling infection is further highlighted in previous studies, such as the expression of $\mathrm{ClCa} 3$ on airway goblet cells, which drives mucin production after infection [50] and the fact that P. carinii can bind to rat epithelial cells [28]. In summary, these studies indicated a fundamental role for $\mathrm{CD}^{+} \mathrm{T}$ cell-mediated responses to Pneumocystis infection and also highlighted the participation of host airway cells in the immune response against Pneumocystis.

$\mathrm{CD} 8^{+} \mathrm{T}$ cells are thought to work in conjunction with $\mathrm{CD} 4^{+} \mathrm{T}$ cells to elicit an effective immune response against Pneumocystis. The role of $\mathrm{CD}^{+} \mathrm{T}$ cells in the absence of $\mathrm{CD} 4^{+} \mathrm{T}$ cells remains controversial, with reports of both protective and detrimental responses. Early studies by Kolls et al. showed that IFN- $\gamma$ resulted in an increase in IFN- $\gamma^{+} \mathrm{CD} 8^{+} \mathrm{T}$ cells, which enhanced effective clearance of Pneumocystis infection in the absence of $\mathrm{CD}^{+} \mathrm{T}$ cells [46]. In addition, in vitro studies by Mc Allister et al. showed that IFN- $\gamma$-stimulated $\mathrm{CD} 8^{+} \mathrm{T}$ cells derived from $\mathrm{CD} 4^{+}$-depleted Pneumocystis-infected mice were able to enhance macrophage-mediated killing [33]. Recently, a study by Ruan et al. demonstrated that the continual administration of recombinant human IL-7 (rhIL-7) to CD4 ${ }^{+}$depleted mice resulted in an increase in both $\mathrm{CD} 8^{+} \mathrm{T}$ cells and $\mathrm{CD} 8^{+}$memory $\mathrm{T}$ cells recruited to the lungs. This was correlated 
to Pneumocystis clearance. Additionally, they demonstrated that rhIL-7 administration enhanced lymphocyte function, including activation, proliferation and IFN- $\gamma$ expression, and reduced cell death at the site of infection [34]. Human IL-7 has been shown to bind and signal via the murine IL-7 receptor, and the authors therefore speculated that the response is due to the increment of IFN- $\gamma$-secreting $\mathrm{CD}^{+} \mathrm{T}$ cells, that are cytotoxic to P. murina, at the site of infection. On the other hand, a study by Gigliotti et al. indicated no difference in the lung burden between $\mathrm{CD}^{+}$and $\mathrm{CD} 8^{+} \mathrm{T}$ cell-depleted mice, suggesting that the role of $\mathrm{CD}^{+} \mathrm{T}$ cells in P. murina clearance is questionable [51]. Further investigation of the role of $\mathrm{CD} 8^{+} \mathrm{T}$ cells in Pneumocystis infection focussed on secondary immune responses. De la Rua and colleagues suggested that secondary immune responses involve $\mathrm{CD} 8^{+} \mathrm{T}$ cells and alveolar macrophages. Briefly, $\mathrm{CD} 8^{+} \mathrm{T}$ cells and macrophage depletion prior to a secondary infection significantly impairs Pneumocystis clearance compared with $\mathrm{CD} 4^{+}$depleted mice, which clears infection within $48 \mathrm{~h}$, comparable to immunocompetent mice. Furthermore, the loss of alveolar macrophages resulted in an increase in IFN- $\gamma^{+} \mathrm{CD} 8^{+} \mathrm{T}$ cells [52]. These studies showed evidence of the role of $\mathrm{CD} 8^{+} \mathrm{T}$ cells in Pneumocystis clearance. The role of $\mathrm{CD}^{+} \mathrm{T}$ cells remains controversial, and one would need to consider other potential causes for the conflicting results. These could be influenced by, for example, the life-cycle stages present in lung homogenates from infected lungs and the method used for immunosuppressing experimental animals.

Susceptibility to Pneumocystis is also influenced by B cells, which play a dual role in antibody production and antigen presentation [53]. Firstly, B cells are important in T cell priming during the primary stage of Pneumocystis infection. Lund et al. demonstrated that cognate B-T cell interactions are important for the generation of both effector and memory CD4 ${ }^{+} \mathrm{T}$ cells in Pneumocystis infection [54]. Opata et al. went further to show that these B cells play an important role in early priming of $\mathrm{CD} 4^{+} \mathrm{T}$ cells [55]. Both studies highlighted the significance of MHC class II expression in B cells, where the lack thereof results in defective $\mathrm{CD} 4^{+} \mathrm{T}$ cell immunity and susceptibility to Pneumocystis. Immunoglobulin $\mathrm{M}(\operatorname{IgM})$ is key in fungal recognition by dendritic cells, B cell isotype class-switching and Th2 and Th17 promotion of differentiation. CD20 is a membrane-bound surface molecule expressed on B cells and is important in the development and differentiation of $\mathrm{B}$ cells into plasma cells. Mice lacking IgM and those treated with anti-CD20 exhibit $\mathrm{CD}^{+} \mathrm{T}$ cell priming defects $[56,57]$. On the contrary, patients with $B$ cell disorders such as $x$-linked agammaglobulinemia and common variable immunodeficiency (CVID) are reported to rarely present with $\mathrm{PCP}$, suggesting a B cell-independent $\mathrm{CD} 4^{+} \mathrm{T}$ cell priming mechanism. In terms of antibody production, Gigliotti et al. [58] and Zheng et al. [59] demonstrated that the passive transfer of immune serum averts Pneumocystis infection. These studies suggested that $\mathrm{B}$ cells play a role in $\mathrm{CD} 4^{+} \mathrm{T}$ cell priming and as effector cells.

Taken together, Pneumocystis infection activates Th1, Th2 and Th17 responses which are implicated in the immune response to Pneumocystis. However, Th2 and Th17 responses can also induce pathology in competent hosts. $\mathrm{CD}^{+} \mathrm{T}$ cells play a role in secondary immune responses, and B cells are important antigen-presenting and effector cells in Pneumocystis infection.

\section{Conclusions}

Significant progress has been made in understanding the host immune response to Pneumocystis. Dendritic cells play a central role in initiating these immune responses, which are influenced by $\beta$-glucan recognition from specific Pneumocystis life forms. The role of alveolar macrophages as key effector cells in clearing Pneumocystis is undisputed. However, the macrophage activation status seems to be of importance and is dependent on the immune status of the host. M1 macrophages in an immunocompromised host are defective, and adoptive transfer of M2 macrophages assists in clearance. $\mathrm{CD}^{+} \mathrm{T}$ cells are essential in controlling Pneumocystis infection, but the specific $\mathrm{T}$ helper cell subset that is indispensable is yet to be determined. This is likely due to potential compensatory mechanisms that control infection in the absence of specific subsets. Furthermore, both Th2 and Th17 responses have been associated with Pneumocystis-driven pathology. CD8 ${ }^{+} \mathrm{T}$ cells play a role in memory recall responses in the absence of $\mathrm{CD} 4^{+} \mathrm{T}$ cells, and $\mathrm{B}$ cells are important in $\mathrm{CD} 4^{+} \mathrm{T}$ cell priming and as 
effector cells. Understanding the role host cells play in the protection against Pneumocystis infection and identifying components that contribute to disease progression could lead to developing better treatment options. New treatment strategies will prove essential, on the basis of reports of the increase in PCP cases and drug resistance.

Author Contributions: P.O. and S.W. wrote the manuscript. J.C.H. revised and edited the final version of the manuscript.

Funding: P.O. is supported by the University of Cape Town and Margaret McNamara Education Grants. S.W. is supported by the European \& Developing Countries Clinical Trials Partnership (CDF1018) and Wellcome Trust (203135/Z/16/Z). J.C.H. is supported by the National Research Foundation of South Africa (91464), Medical Research Council of South Africa and Wellcome Trust (209293/Z/17/Z).

Conflicts of Interest: The authors declare no conflict of interest. The funders had no role in design, data collection and preparation of the manuscript.

\section{References}

1. Morris, A.; Norris, K.A. Colonization by Pneumocystis jirovecii and its role in disease. Clin. Microbiol. Rev. 2012, 25, 297-317. [CrossRef] [PubMed]

2. Ma, L.; Cisse, O.H.; Kovacs, J.A. A Molecular Window into the Biology and Epidemiology of Pneumocystis spp. Clin. Microbiol. Rev. 2018, 31. [CrossRef] [PubMed]

3. Buchacz, K.; Baker, R.K.; Palella, F.J., Jr.; Chmiel, J.S.; Lichtenstein, K.A.; Novak, R.M.; Wood, K.C.; Brooks, J.T.; HOPS Investigators. AIDS-defining opportunistic illnesses in US patients, 1994-2007: A cohort study. AIDS 2010, 24, 1549-1559. [CrossRef] [PubMed]

4. Kelley, C.F.; Checkley, W.; Mannino, D.M.; Franco-Paredes, C.; Del Rio, C.; Holguin, F. Trends in hospitalizations for AIDS-associated Pneumocystis jirovecii Pneumonia in the United States (1986 to 2005). Chest 2009, 136, 190-197. [CrossRef] [PubMed]

5. Kovacs, J.A.; Masur, H. Evolving health effects of Pneumocystis: One hundred years of progress in diagnosis and treatment. JAMA 2009, 301, 2578-2585. [CrossRef] [PubMed]

6. Rodriguez, M.; Fishman, J.A. Prevention of infection due to Pneumocystis spp. in human immunodeficiency virus-negative immunocompromised patients. Clin. Microbiol. Rev. 2004, 17, 770-782. [CrossRef]

7. Bienvenu, A.L.; Traore, K.; Plekhanova, I.; Bouchrik, M.; Bossard, C.; Picot, S. Pneumocystis pneumonia suspected cases in 604 non-HIV and HIV patients. Int. J. Infect. Dis. 2016, 46, 11-17. [CrossRef]

8. Maini, R.; Henderson, K.L.; Sheridan, E.A.; Lamagni, T.; Nichols, G.; Delpech, V.; Phin, N. Increasing Pneumocystis pneumonia, England, UK, 2000-2010. Emerg. Infect. Dis. 2013, 19, 386-392. [CrossRef]

9. Monnet, X.; Vidal-Petiot, E.; Osman, D.; Hamzaoui, O.; Durrbach, A.; Goujard, C.; Miceli, C.; Bourée, P.; Richard, C. Critical care management and outcome of severe Pneumocystis pneumonia in patients with and without HIV infection. Crit. Care 2008, 12, R28. [CrossRef]

10. Wang, E.H.; Partovi, N.; Levy, R.D.; Shapiro, R.J.; Yoshida, E.M.; Greanya, E.D. Pneumocystis pneumonia in solid organ transplant recipients: Not yet an infection of the past. Transpl. Infect. Dis. 2012, 14, 519-525. [CrossRef]

11. Fillatre, P.; Decaux, O.; Jouneau, S.; Revest, M.; Gacouin, A.; Robert-Gangneux, F.; Fresnel, A.; Guiguen, C.; Le Tulzo, Y.; Jégo, P.; et al. Incidence of Pneumocystis jiroveci pneumonia among groups at risk in HIV-negative patients. Am. J. Med. 2014, 127, 1242. [CrossRef]

12. Su, Y.S.; Lu, J.J.; Perng, C.L.; Chang, F.Y. Pneumocystis jirovecii pneumonia in patients with and without human immunodeficiency virus infection. J. Microbiol. Immunol. Infect. 2008, 41, 478-482. [PubMed]

13. Limper, A.H.; Offord, K.P.; Smith, T.F.; Martin, W.J., 2nd. Pneumocystis carinii pneumonia. Differences in lung parasite number and inflammation in patients with and without AIDS. Am. Rev. Respir. Dis. 1989, 140, 1204-1209. [CrossRef]

14. Thomas, C.F., Jr.; Limper, A.H. Pneumocystis pneumonia. N. Engl. J. Med. 2004, 350, 2487-2498. [CrossRef] [PubMed]

15. Festic, E.; Gajic, O.; Limper, A.H.; Aksamit, T.R. Acute respiratory failure due to pneumocystis pneumonia in patients without human immunodeficiency virus infection: Outcome and associated features. Chest 2005, 128, 573-579. [CrossRef] 
16. De Armas Rodriguez, Y.; Wissmann, G.; Muller, A.L.; Pederiva, M.A.; Brum, M.C.; Brackmann, R.L.; Capó de Paz, V.; Calderón, E.J. Pneumocystis jirovecii pneumonia in developing countries. Parasite 2011, 18, $219-228$. [CrossRef]

17. Wasserman, S.; Engel, M.E.; Griesel, R.; Mendelson, M. Burden of pneumocystis pneumonia in HIV-infected adults in sub-Saharan Africa: A systematic review and meta-analysis. BMC Infect. Dis. 2016, 16. [CrossRef]

18. Chiliza, N.; Du Toit, M.; Wasserman, S. Outcomes of HIV-associated pneumocystis pneumonia at a South African referral hospital. PLoS ONE 2018, 13, e0201733. [CrossRef]

19. Cushion, M.T.; Smulian, A.G.; Slaven, B.E.; Sesterhenn, T.; Arnold, J.; Staben, C.; Porollo, A.; Adamczak, R.; Meller, J. Transcriptome of Pneumocystis carinii during fulminate infection: Carbohydrate metabolism and the concept of a compatible parasite. PLoS ONE 2007, 2, e423. [CrossRef] [PubMed]

20. Hauser, P.M. Genomic Insights into the Fungal Pathogens of the Genus Pneumocystis: Obligate Biotrophs of Humans and Other Mammals. PLoS Pathog. 2014, 10, e1004425. [CrossRef] [PubMed]

21. Matsumura, Y.; Tsuchido, Y.; Yamamoto, M.; Nakano, S.; Nagao, M. Development of a fully automated PCR assay for the detection of Pneumocystis jirovecii using the GENECUBE system. Med. Mycol. 2018. [CrossRef] [PubMed]

22. Singh, Y.; Mirdha, B.R.; Guleria, R.; Kabra, S.K.; Mohan, A.; Chaudhry, R.; Kumar, L.; Dwivedi, S.N.; Agarwal, S.K. Genetic polymorphisms associated with treatment failure and mortality in pediatric Pneumocystosis. Sci. Rep. 2019, 9, 1192. [CrossRef]

23. Cushion, M.T.; Ruffolo, J.J.; Walzer, P.D. Analysis of the developmental stages of Pneumocystis carinii, in vitro. Lab. Investig. J. Tech. Methods Pathol. 1988, 58, 324-331.

24. Evans, H.M.; Bryant, G.L.; Garvy, B.A. The life cycle stages of Pneumocystis murina have opposing effects on the immune response to this opportunistic, fungal pathogen. Infect. Immun. 2016, 84, 3195-3205. [CrossRef] [PubMed]

25. Kottom, T.J.; Hebrink, D.M.; Jenson, P.E.; Gudmundsson, G.; Limper, A.H. Evidence for Proinflammatory ß-1,6 Glucans in the Pneumocystis carinii Cell Wall. Infect. Immun. 2015, 83, 2816-2826. [CrossRef] [PubMed]

26. Evans, H.M.; Simpson, A.; Shen, S.; Stromberg, A.J.; Pickett, C.L.; Garvy, B.A. The Trophic Life Cycle Stage of the Opportunistic Fungal Pathogen Pneumocystis murina Hinders the Ability of Dendritic Cells to Stimulate $\mathrm{CD}^{+}{ }^{+} \mathrm{T}$ Cell Responses. Infect. Immun. 2017, 85. [CrossRef]

27. Evans, H.M.; Garvy, B.A. The trophic life cycle stage of Pneumocystis species induces protective adaptive responses without inflammation-mediated progression to pneumonia. Med. Mycol. 2018, 56, 994-1005. [CrossRef]

28. Kottom, T.J.; Hebrink, D.M.; Limper, A.H. Binding of Pneumocystis carinii to the lung epithelial cell receptor HSPA5 (GRP78). J. Med. Microbiol. 2018, 67, 1772-1777. [CrossRef]

29. Perez-Nazario, N.; Rangel-Moreno, J.; O’Reilly, M.A.; Pasparakis, M.; Gigliotti, F.; Wright, T.W. Selective ablation of lung epithelial IKK2 impairs pulmonary Th17 responses and delays the clearance of Pneumocystis. J. Immunol. 2013, 191, 4720-4730. [CrossRef]

30. Eddens, T.; Campfield, B.T.; Serody, K.; Manni, M.L.; Horne, W.; Elsegeiny, W.; McHugh, K.J.; Pociask, D.; Chen, K.; Zheng, M.; et al. A Novel CD4 ${ }^{+} \mathrm{T}$ Cell-Dependent Murine Model of Pneumocystis-driven Asthma-like Pathology. Am. J. Respir. Crit. Care Med. 2016, 194, 807-820. [CrossRef]

31. Iturra, P.A.; Rojas, D.A.; Pérez, F.J.; Méndez, A.; Ponce, C.A.; Bonilla, P.; Bustamante, R.; Rodríguez, H.; Beltrán, C.J.; Vargas, S.L. Progression of type 2 helper T cell-type inflammation and airway remodeling in a rodent model of naturally acquired subclinical primary pneumocystis infection. Am. J. Pathol. 2018, 188, 417-431. [CrossRef]

32. Rojas, D.A.; Iturra, P.A.; Méndez, A.; Ponce, C.A.; Bustamante, R.; Gallo, M.; Bórquez, P.; Vargas, S.L. Increase in secreted airway mucins and partial Muc5b STAT6/FoxA2 regulation during Pneumocystis primary infection. Sci. Rep. 2019, 14, 2078. [CrossRef]

33. McAllister, F.; Mc Allister, F.; Steele, C.; Zheng, M.; Young, E.; Shellito, J.E.; Marrero, L.; Kolls, J.K. T cytotoxic-1 $\mathrm{CD}^{+} \mathrm{T}$ cells are effector cells against pneumocystis in mice. J. Immunol. 2004, 172, 1132-1138. [CrossRef]

34. Ruan, S.; Samuelson, D.R.; Assouline, B.; Morre, M.; Shellito, J.E. Treatment with Interleukin-7 Restores Host Defense against Pneumocystis in CD4+ T-Lymphocyte-Depleted Mice. Infect. Immun. 2016, 84, 108-119. [CrossRef] 
35. Carmona, E.M.; Vassallo, R.; Vuk-Pavlovic, Z.; Standing, J.E.; Kottom, T.J.; Limper, A.H. Pneumocystis cell wall beta-glucans induce dendritic cell costimulatory molecule expression and inflammatory activation through a Fas-Fas ligand mechanism. J. Immunol. 2006, 177, 459-467. [CrossRef] [PubMed]

36. Carmona, E.M.; Kottom, T.J.; Hebrink, D.M.; Moua, T.; Singh, R.-D.; Pagano, R.E.; Limper, A.H. Glycosphingolipids mediate pneumocystis cell wall $\beta$-glucan activation of the IL-23/IL-17 axis in human dendritic cells. Am. J. Respir. Cell Mol. Biol. 2012, 47, 50-59. [CrossRef]

37. Sassi, M.; Kutty, G.; Ferreyra, G.A.; Bishop, L.R.; Liu, Y.; Qiu, J.; Huang, D.W.; Kovacs, J.A. The Major Surface Glycoprotein of Pneumocystis murina Does Not Activate Dendritic Cells. J. Infect. Dis. 2018, 218, 1631-1640. [CrossRef]

38. Limper, A.H.; Hoyte, J.S.; Standing, J.E. The role of alveolar macrophages in Pneumocystis carinii degradation and clearance from the lung. J. Clin. Investig. 1997, 99, 2110-2117. [CrossRef] [PubMed]

39. Leopold Wager, C.M.; Wormley, F.L. Classical versus alternative macrophage activation: The Ying and the Yang in host defense against pulmonary fungal infections. Mucosal. Immunol. 2014, 7, 1023-1035. [CrossRef]

40. Nandakumar, V.; Hebrink, D.; Jenson, P.; Kottom, T.; Limper, A.H. Differential Macrophage Polarization from Pneumocystis in Immunocompetent and Immunosuppressed Hosts: Potential Adjunctive Therapy during Pneumonia. Infect. Immun. 2017, 85. [CrossRef]

41. Bhagwat, S.P.; Gigliotti, F.; Wang, J.; Wang, Z.; Notter, R.H.; Murphy, P.S.; Rivera-Escalera, F.; Malone, J.; Jordan, M.B.; Elliott, M.R.; et al. Intrinsic Programming of Alveolar Macrophages for Protective Antifungal Innate Immunity against Pneumocystis Infection. Front. Immunol. 2018, 9, 2131. [CrossRef] [PubMed]

42. Rudner, X.L.; Happel, K.I.; Young, E.A.; Shellito, J.E. Interleukin-23 (IL-23)-IL-17 cytokine axis in murine Pneumocystis carinii infection. Infect. Immun. 2007, 75, 3055-3061. [CrossRef] [PubMed]

43. Ripamonti, C.; Bishop, L.R.; Kovacs, J.A. Pulmonary Interleukin-17-Positive Lymphocytes Increase during Pneumocystis murina Infection but Are Not Required for Clearance of Pneumocystis. Infect. Immun. 2017, 85. [CrossRef] [PubMed]

44. Elyaman, W.; Bradshaw, E.M.; Uyttenhove, C.; Dardalhon, V.; Awasthi, A.; Imitola, J.; Bettelli, E.; Oukka, M.; van Snick, J.; Renauld, J.-C.; et al. IL-9 induces differentiation of TH17 cells and enhances function of FoxP3+ natural regulatory T cells. Proc. Natl. Acad. Sci. USA 2009, 106, 12885-12890. [CrossRef] [PubMed]

45. Li, T.; Rong, H.-M.; Zhang, C.; Zhai, K.; Tong, Z.-H. IL-9 Deficiency Promotes Pulmonary Th17 Response in Murine Model of Pneumocystis Infection. Front. Immunol. 2018, 9, 1118. [CrossRef] [PubMed]

46. Kolls, J.K.; Habetz, S.; Shean, M.K.; Vazquez, C.; Brown, J.A.; Lei, D.; Schwarzenberger, P.; Ye, P.; Nelson, S.; Summer, W.R.; et al. IFN- $\gamma$ and CD8 ${ }^{+}$T Cells Restore Host Defenses Against Pneumocystis carinii in Mice Depleted of CD4+ T Cells. J. Immunol. 1999, 162, 2890-2894. [PubMed]

47. Myers, R.C.; Dunaway, C.W.; Nelson, M.P.; Trevor, J.L.; Morris, A.; Steele, C. STAT4-dependent and -independent Th2 responses correlate with protective immunity against lung infection with Pneumocystis murina. J. Immunol. 2013, 190, 6287-6294. [CrossRef] [PubMed]

48. Eddens, T.; Elsegeiny, W.; Nelson, M.P.; Horne, W.; Campfield, B.T.; Steele, C.; Kolls, J.K. Eosinophils Contribute to Early Clearance of Pneumocystis murina Infection. J. Immunol. 2015, 195, 185-193. [CrossRef] [PubMed]

49. Vargas, S.L.; Ponce, C.A.; Gallo, M.; Pérez, F.; Astorga, J.F.; Bustamante, R.; Chabé, M.; Durand-Joly, I.; Iturra, P.; Miller, R.F.; et al. Near-universal prevalence of Pneumocystis and associated increase in mucus in the lungs of infants with sudden unexpected death. Clin. Infect. Dis. 2013, 2, 171-179. [CrossRef]

50. Hernandez-Novoa, B.; Bishop, L.; Logun, C.; Munson, P.J.; Elnekave, E.; Rangel, Z.G.; Barb, J.; Danner, R.L.; Kovacs, J.A. Immune responses to Pneumocystis murina are robust in healthy mice but largely absent in CD40 ligand-deficient mice. J. Leukoc. Biol. 2008, 84, 420-430. [CrossRef]

51. Gigliotti, F.; Crow, E.L.; Bhagwat, S.P.; Wright, T.W. Sensitized CD8 ${ }^{+}$T cells fail to control organism burden but accelerate the onset of lung injury during Pneumocystis carinii pneumonia. Infect. Immun. 2006, 74, 6310-6316. [CrossRef] [PubMed]

52. De la Rua, N.M.; Samuelson, D.R.; Charles, T.P.; Welsh, D.A.; Shellito, J.E. CD4 ${ }^{+}$T-Cell-Independent Secondary Immune Responses to Pneumocystis Pneumonia. Mucosal. Immun. 2016, 178. [CrossRef]

53. Kolls, J.K. An Emerging Role of B Cell Immunity in Susceptibility to Pneumocystis Pneumonia. Am. J. Respir. Cell Mol. Biol. 2017, 56, 279-280. [CrossRef] [PubMed] 
54. Lund, F.E.; Hollifield, M.; Schuer, K.; Lines, J.L.; Randall, T.D.; Garvy, B.A. B cells are required for generation of protective effector and memory CD4 cells in response to Pneumocystis lung infection. J. Immunol. 2006, 176, 6147-6154. [CrossRef] [PubMed]

55. Opata, M.M.; Hollifield, M.L.; Lund, F.E.; Randall, T.D.; Dunn, R.; Garvy, B.A.; Feola, D.J. B Lymphocytes Are Required during the Early Priming of $\mathrm{CD}^{+} \mathrm{T}$ Cells for Clearance of Pneumocystis Infection in Mice. J. Immunol. 2015, 195, 611-620. [CrossRef]

56. Rapaka, R.R.; Ricks, D.M.; Alcorn, J.F.; Chen, K.; Khader, S.A.; Zheng, M.; Plevy, S.; Bengtén, E.; Kolls, J.K. Conserved natural IgM antibodies mediate innate and adaptive immunity against the opportunistic fungus Pneumocystis murina. J. Exp. Med. 2010, 207, 2907-2919. [CrossRef]

57. Elsegeiny, W.; Eddens, T.; Chen, K.; Kolls, J.K. Anti-CD20 Antibody Therapy and Susceptibility to Pneumocystis Pneumonia. Infect. Immun. 2015, 83, 2043-2052. [CrossRef] [PubMed]

58. Gigliotti, F.; Haidaris, C.G.; Wright, T.W.; Harmsen, A.G. Passive intranasal monoclonal antibody prophylaxis against murine Pneumocystis carinii pneumonia. Infect. Immun. 2002, 70, 1069-1074. [CrossRef] [PubMed]

59. Zheng, M.; Shellito, J.E.; Marrero, L.; Zhong, Q.; Julian, S.; Ye, P.; Wallace, V.; Schwarzenberger, P.; Kolls, J.K. $\mathrm{CD}^{+} \mathrm{T}$ cell-independent vaccination against Pneumocystis carinii in mice. J. Clin. Investig. 2001, 108, 1469-1474. [CrossRef]

(C) 2019 by the authors. Licensee MDPI, Basel, Switzerland. This article is an open access article distributed under the terms and conditions of the Creative Commons Attribution (CC BY) license (http://creativecommons.org/licenses/by/4.0/). 